\title{
A Typical Instrument for Assessing the Genre-Based Writing
}

\author{
I Wy. Dirgeyasa ${ }^{1}$ \\ ${ }^{1}$ Universitas Negeri Medan, Indonesia
}

\begin{tabular}{l}
\hline \hline ARTICLE INFO \\
\hline \hline Article history: \\
Received Aug 05, 2020 \\
Revised Sept 07, 2020 \\
Accepted Sept 19, 2020 \\
\hline
\end{tabular}

\section{Keywords:}

genre based writing, instrument, assessment,

\section{Clonflict of Interest:}

None

\section{Funding:}

None

\begin{abstract}
Recently, it is a fact that the genre-based writing English Curriculum in Indonesia either in high or higher education has been implemented for years. Unfortunately, it seems that the student's writing is not assessed in accordance to the nature of genre based writing itself yet. As a matter of fact, assessment plays important role to success of teaching and learning. A proper assessment instrument leads to the valid and reliable learning achievement or otherwise. In terms of genre based writing, as a typical approach to teaching and learning writing also needs the assessment instrument meeting the nature of the genre based writing itself. This paper is aiming at providing a preliminary understanding and sights of typical instrument for assessing the genre based writing.
\end{abstract}

Corresponding Author: I Wy. Dirgeyasa, English Department Faculty of Languages and Arts State University of Medan. Tel: +62 82162130480. E-mail: wayandirgayasa@yahoo.com.

\section{Introduction}

In Indonesian education context, the government has always afforded seriously to design and develop the English curriculum which enables the students to master the English proficiently in the last ten years. By having a good English proficiency and skill, the students finally can use English as a means of communication either in spoken and written form for their life in the future.

In doing so, the government, especially Minister of Education and Culture developed English curriculum known as Kurikulum Tingkat Satuan Pendidikan (KTSP) in 2006 and 2013 English curriculum (K-13). Even though the KTSP English curriculum has been revised to be 2013 English curriculum, still English curriculum, in term of writing skill is designed and developed based on a genre approach (hereafter genrebased writing-GBW).

So what is genre based writing? In terms of writing, the genre is defined as a writing form having its own typical features or characteristics. The writing with the features and characteristics of genre-based writing, of course is different from the other writing form viewed from different perspectives (Dirgeyasa,2014a). Genrebased writing has its own uniqueness and characteristics because it is connected with social context in which the writing is used. Even though Genre-based approach to writing is actually appropriate for students of English for Specific Purposes. However, it is also highly useful for general English, even at low level (Harmer, 2009).

Even though, the genre-based writing to teaching and learning writing in the last ten years has been implemented in schools and universities, there are seemingly some problems, constraints, and mismatches, 
regarding to the process of teaching and learning writing through genre-based writing and assesment model used to assess the students' writing. (Dirgeyasa, 2014a).

First, it seems that the teachers and lectures are having diverse understanding and competences regarding to genre-based writing. Dirgeyasa (2014a) in his article reports that one of the among six constraints and problems to teaching genre-based writing at school and university is the lack of knowledge among the teachers and lecturers. This condition leads to deviation and confusion in order to understand the genre writing among the students.

Second, the process of teaching and learning of writing is not in line with model of teaching and learning of genre-based writing known as genre-based cycle of teaching and learning as proposed by (Vygotsky, 1978) in (Kroll, 2003). Generally, teachers and lecturer still teach writing by using conventional method in which they tend to explain the concept, give the example of writing, and students start to follow the model given. The students are not guided to implement the cyclic model of genre-based approach to teaching and learning yet. In fact, it actually supports or 'scaffolds' the learners through an interactive process of analysis, discussion, and joint and individual construction of text. In addition, this model of cyclic teaching and learning writing really helps the students learn to write from the very simple and assisted process up to the individual and independent one.

Third, the teachers and lecturers still seemingly have perceptions that genre-based writing is just a matter of the type of text or the typical writing itself. They do not pay much attention that genre-based writing also covers the teaching and learning model. By this condition, they just focus on the study of text types rather than how to teach and learn genre-based writing. This is clearly stated that genre writing as a new approach to teaching and learning, truly combines two things-the product of the writing itself and the way or technique or strategy how the writing is produced (Ann, 2002). So, it is a kind of a coin with two facets (Dirgeyasa, 2014b).

Fourth, observing and documenting the students' writing assessement model used by the teachers and lecturers, it was found that they still assess the students' writing through synthentic model in which the students' writing works are assessed generally without considering and analyzing the components of writing such content, organization, grammatical pattern, mechanics, etc. In addition, even some teachers and lecturers use analytical method of writing assessment, still they use the instrument for assessing writing proposed by some experts such as (Glass, 2005; Heaton, 1989; Brown, 2004) by including the components of writing such content, organization, grammatical pattern, mechanics, etc. However, this of course, is not in accordance with the genre-based writing features and characteritics. This model may be appropriate for writing without genre-based approach.

Finally, the reality of genre-based writing asssesment currently used by the teachers and lectures happen due to the some reasons such as the unavaliability of a genre-based assessment model, the practical and pragmatic reasons, the lack of knowledge and understanding toward the genre-based writing assessment model of the teachers and lecturers, etc.

Concerning the real and sporadic phenomena in assessing genre-based writing accros the schools and universities in the countries, it is important to introduce a model of genre-based writing assessment. It seems that it is not only important and significant but also it is truly urgent to design and develop a appropriatemodel of genre-based writing assessment meeting every type of genre-based writing itself. This paper is aiming at providing a preliminary understanding and sights of typical instrument for assessing the genre based writing.

\section{Discussion}

The Genre-Based Writing Approach

Writing text types by names could be different and typical ones in accordance their approaches. For example, by traditional terms or (non-genre approach) writing can be classified into descriptive, argumentative, expository etc. Then, by genre approach writing text types vary by its name such as descriptive, narrative, review, annecdote, etc. By genre approach, writing text becomes very typical and distintive one. The typicality of writing genre-based approach covers a) textual structure or generic structure, social function, and linguistic features. This means that every text or writing type will be different in terms of its structure, linguistic features, reader, and purpose. In terms of genre-based writing (Hyland, 2003); (Knapp and Watkins, 2005). 
Therefore, every different type of writing has its own characteristics and features showing that one is really different from another one (Knapp and Watkins, 2005; Pardiyono, 2007; Dirgeyasa, 2014b). In addition, they also state that the characteristics of genre-based writing consists of a) certain communicative purpose, b) certain rethorical structure or generic structure and c) certain linguistic features. In addition, the genre also has its own styles and registers (Andrew, 2002; Knapp and Watkins, 2005; Pardiyono 2007).

By its physical structure, each genre-based writing has different elements of text either by names or number. One particular genre may be simple and the other one may be complex in term structure. For example, descriptive genre consists of 'identification' and 'description' in terms of rethorical structure, and the linguistics features used tends to be present tense and adjectives, and so forth. On the other hand, the recount genre consists of (Orientation) $\wedge^{\wedge}$ (Record of event) $\wedge^{\wedge}$ (Re-orientation). Or the procedure text has (topic + statement of purpose) $)^{\wedge}$ (Squences of steps to accomplish job or activities stated in the topic) ${ }^{\wedge}$ (Closing- if necessary) and so forth. In detail table 1 below shows the generic structure, textual elements, and function of recount genre-based writing.

Table 1 the generic structure and textual elements and functions of recount genre-based writing.

\begin{tabular}{|c|c|c|}
\hline $\begin{array}{l}\text { Textual } \\
\text { Elements }\end{array}$ & & Functions \\
\hline Orientation & & $\begin{array}{l}\text { - It consists of theme or topic to be informed. } \\
\text { - To show the reader about the topic/theme being informed. } \\
\text { - To attract reader's attention and interest. } \\
\text { - It enables to attract and to provoke the reader so that he/she is willing } \\
\text { to continue reading the whole text. }\end{array}$ \\
\hline $\begin{array}{l}\text { Record } \\
\text { events } \\
\text { sequence } \\
\text { events }\end{array}$ & $\begin{array}{l}\text { of } \\
\text { or } \\
\text { of }\end{array}$ & $\begin{array}{l}\text { - To provide details about the event informed/described chronologically } \\
\text { (the type of plot may vary). } \\
\text { - It is better to tell chronologically rather than flash back and zigzag. In } \\
\text { order to have a good chronological order the sequence markers such } \\
\text { as first, second, third, etc. are important. }\end{array}$ \\
\hline Re-orientation & & $\begin{array}{l}\text { - It functions to show personal attitude about the activities or event } \\
\text { informed or told of record of event. } \\
\text { - It is a matter of conclusion with personal attitude. }\end{array}$ \\
\hline
\end{tabular}

Dirgeyasa (2014b)

\section{The Preliminary Genre Writing Assessment Model}

Theoritically and empircally, it would be better that the writing should be assessed by analytical scoring or analytical method rather then synthentical scoring or synthetical method. Hyland (2003) states that analytical scoring procedures requires the reader to judge a text against a set of criteria seen as important to good writing. He further argues that analytical score more clearly defines the features to be assessed by separating, and sometimes weighting, individual components and is therefore more effective in discriminating weaker text. By this criteria, the analytical score really assists the raters to assess the closer and more qualified writing work.

In practical implmentation, there are a large number of terms and criteria used in this model of assessment. Glass (2005) proposes five criteria and indicators used for writing assessment such as ideas and content, organization, sentence fluency, word choice, voice, and convention. In line with the use of analytical model, Brown (2004) states that the classroom evaluation of learning is best served through analytical scoring, in which as many as six major elements of writing are scored, thus enabling the students to home in on weaknesses and to capitalize on the strengths. But, again they are not really in line and relevant to the genrebased writing.

In line with genre-based writing, analytical model provides more relevant and appropriate indicators and items to be assessed. Consequently, the result of assessement, of course, would be more valid, reliable, and significant. To do so, the assessment instrument should be designed and developed in accordance to principles, features and characteristics of genre based writing. This is done in order to meet need of the genre-based writing.

Therefore, the assessment instrument needs improving, modifying, and adjusting in accordance to the type of genre-based writing text repectively. Of course, the basic criteria and indicators for every type of genre-based 
writing text will be different one another then. For example, the details of recount text are different from the details of procedure text, narrative text, anecdote text etc. Table 2 below shows the preliminary assessment model for recount genre-based writing is designed and developed.

Table 2 The preliminary assessment instrument for recount genre-based writing.

\begin{tabular}{ll}
\hline No & Performance Indicators \\
\cline { 2 - 4 } & $\begin{array}{l}\text { First paragraph introduces the topic clearly and } \\
\text { grabs the reader's attention. }\end{array}$ \\
\hline 2 & $\begin{array}{l}\text { The content/idea of the text is in line with the } \\
\text { topic/title. }\end{array}$ \\
\hline 3 & Overall writing makes sense/ has a clear message. \\
\hline 4 & $\begin{array}{l}\text { A series of events run in a chronological (time) } \\
\text { order }\end{array}$ \\
\hline 5 & $\begin{array}{l}\text { The background information covers the words } \\
\text { who, what, where and when. }\end{array}$ \\
\hline 6 & The paragraphs run cohesively and coherently. \\
\hline 7 & $\begin{array}{l}\text { The text structure/generic structure meets the } \\
\text { nature of recount generic structure. }\end{array}$ \\
\hline 8 & $\begin{array}{l}\text { The structural patterns follow the conventions of } \\
\text { English language and in line with the recount text. }\end{array}$ \\
\hline 10 & $\begin{array}{l}\text { The vocabulary and word choices, including } \\
\text { temporal conjunctions, are clear and correctly and } \\
\text { properly used. }\end{array}$ \\
\hline
\end{tabular}

Table 2 above shows that the assessment instrument consists of performance indicators and scale or grade. The scale 5, 4, 3, 2, and 1 show the quality or value of the item. By this instrument model, the recount genrebased writing can be assessed well and meets the characteristic and feature of recount genre-based writing itself.

This, will of course, be storngly different from other genre writing type such as narrative text. The instrument items and indicators must follow the characterisitcs and features of the narrative text itself. Table 2 below tries to show a preliminary assessment model of narrative genre-based writing.

Table 3 the preliminary assessment model of narrative genre-based writing.

\begin{tabular}{|c|c|c|c|c|c|c|}
\hline \multirow{2}{*}{ No } & \multirow{2}{*}{ Performance Indicators } & \multicolumn{5}{|c|}{ Scores } \\
\hline & & 5 & 4 & 3 & 2 & 1 \\
\hline 1 & $\begin{array}{l}\text { First paragraph introduces the topic clearly, grabs } \\
\text { the reader's attention, and provides information } \\
\text { about the characters and setting. }\end{array}$ & & & & & \\
\hline 2 & $\begin{array}{l}\text { Story relates a series of events that create an } \\
\text { entertaining story with a problem and solution. }\end{array}$ & & & & & \\
\hline 3 & $\begin{array}{l}\text { The content/idea of the text is in line with the } \\
\text { topic/title. }\end{array}$ & & & & & \\
\hline 4 & Overall writing makes sense/ has a clear message. & & & & & \\
\hline
\end{tabular}




\begin{tabular}{ll}
\hline 5 & $\begin{array}{l}\text { Story is finished with complication/problem } \\
\text { resolved in detail. }\end{array}$ \\
\hline 6 & The paragraphs run cohesively and coherently. \\
\hline 7 & $\begin{array}{l}\text { The text structure/generic structure meets the nature } \\
\text { of narrative generic structure. }\end{array}$ \\
\hline 8 & $\begin{array}{l}\text { The structural patterns follow the conventions of } \\
\text { English language and in line with the narrative text. }\end{array}$ \\
\hline 9 & $\begin{array}{l}\text { The vocabulary and word choices, including } \\
\text { temporal conjunctions and temporal circumstances, } \\
\text { are clear and correctly and properly used. }\end{array}$ \\
\hline 10 & It uses correct spelling and it is legible writing. \\
\hline 11 & The text mechanics are correctly and properly used. \\
\hline Total Score \\
\hline Student's Score: Total Score/55x100 \\
\hline Dirgayasa (2014b)
\end{tabular}

\section{Conclusion}

Asssessing writing, particulary a genre based writing approah is regarded complex and difficult to do. Its complexities could be by patterns, forms, types, functions, goals, and linguistic features, etc. Due its complexity, assessing writing could be actually time consuming and is also sometimes frustrating and annoying.

The genre-based writing assessment instrument must be designed and developed in accordance to characteristics and features of genre-based writing itself such as such as communicative purpose, generic structure, and grammatical patterns and vocabulary choices in order to provide a qualified assessment result. That's why every type of genre-based writing has its own typical assessment instrument either in terms of items, content, and number of itmes.

In short, a genre-based writing as a new approach to writing does not only fall into two uniqueness namely its typical writing form and teaching and learning process as what generally known, but it is also its assessment model This clearly shows that genre-based approach is absolutely different from the other approaches such as product approach, content approach, and structure approach, etc.

\section{References}

Ann, John.M. 2002. Genre in the Classroom: Multiple Perspective. New Jersey: Lawrence Erlbaun Associates Publishers.

Badger, Richard dan White Goodwith, 2000. A Process Genre Approach to Teaching Writing by Badger Richard and White Goodwith in ELT Journal No 54/2 April 2000.London: Oxford University Press.

Brown Douglas H. 2004. Language Assessment: Principles and Classroom Practice. New York: Pearson Education, Inc.

2007. Teaching by Principles: An Interactive Approach to Language Pedagogy. New York: Pearson Education, Inc.

Dirgeyasa., I Wy. 2014a. The Development of English Writing Learning Materials through Genre-Based Approach for English Department at University. Proceeding Seminar on English Language and Teaching 2014. English Department, Faculty of Language and Art State University of Padang. 2014b. College Academic Writing: a genre-based perspective. Medan: Unimed Press.

Harmer, Jeramy. 2009. $4^{\text {th }}$ ed. The Practice of English Language Teaching. China: Pearson Longman.

Heaton.JB. 1989. Writing English Language Test. New York: Longman Group.UK.

Hyland Ken, 2002. Teaching and Researching Writing. London: Pearson Publication.

2003. Second Language Writing. London: Cambridge University Press.

Glass, Tuchman K. 2005. Curriculum Design for Writing Instruction. California: Crowin Press 
Knapp, Peter and Watkins. 2005. Genre, Text Grammar: Technologies for Teaching and Assessing Writing. Sydney: University of New South Wales Press Ltd.

Kroll, Barbara. Ed. 2003. Exploring the Dynamics of Second Language Writing.London: Cambridge University Press.

Martin, James R. 1999. Factual Writing: Exploring and Challenging Social Reality. Melbourne: Deakin University Press.

Pardiyono, Pasti Bisa: Teaching Genre Based Writing. Yogyakarta: Penrbit Andi. 2007.

Swales, John.M. Genre Analysis English in Academic and Research Settings: Cambridge: Cambridge University Press.1990.

Stoke, Jane. 2003. How to do Media and Cultural Studies diterjemahkan oleh Santri Indah Astuti. 2006. (Panduan untuk Melaksanakan Penelitian dalam Kajian Media dan Budaya, Yogyakarta: PT. Benteng Pustaka. 